\title{
THE IMPLEMENTATION OF SAVI MODEL WITH ECLIPSE CROSSWORD TO IMPROVE STUDENTS' ACTIVITIES AND LEARNING ACHIEVEMENT OF CUBE ROOTS FOR GRADE VI SEMESTER I IN STATE ELEMENTARY SCHOOL I SANAN, GIRIMARTO DISTRICT, WONOGIRI REGENCY IN THE YEAR 2017/2018
}

\author{
Samsi Suryanjani, Riyadi, Budi Usodo \\ Sebelas Maret University \\ suryanjanisamsi68@gmail.com
}

\section{Article History}

accepted 09/07/2018

approved 01/08/2018

published 17/09/2018

Keywords

SAVI, eclipse crossword, activities, learning

achievement

\begin{abstract}
This study aimed to describe the learning process, the students' activities, and the students' learning achievement of cube roots after the implementation of SAVI model withEclipse Crosswordfor grade VI students. Utilizing an Action Research $(A R)$, the procedures of this study were planning, acting, observing, and reflecting. The participants were 13 students of grade VI from State Elementary School 1 in Sanan, Wonogiri in the academic year 2017/2018. The data were collected through journals of teaching and learning process, observation, post-test, and field notes, and interviews. The study revealed that the students' activities were11.31categorized as inactive in pre-cycle, 15.54 categorized as fairly active in cycle I, and 24.85 categorized as active in cycle II. The students' activities also were categorized as fairly active in cycle I and active in cycle II. Mean of the students' score had an improvement that was 57.69 with the minimum level of the learning mastery $38 \%$ in pre-cycle of grade VI in cube roots' topics, 77.61 with the minimum level of the learning mastery $77 \%$ which had not reached the performance indicator of $80 \%$, and 87.33 with the minimum level of the learning mastery $85 \%$ full filed the performance indicator. Therefore, the further cycle did not need to be conducted anymore. The teachers are suggested to design the lesson plan of SAVI model with Eclipse Crossword in order that the learning tools are designed well so that the students' participation, activities, and learning achievement are above the minimum level of the learning mastery.
\end{abstract}

Social, Humanities, and Education Studies (SHEs): Conference Series https://jurnal.uns.ac.id/shes

p-ISSN 2620-9284 e-ISSN 2620-9292 


\section{PENDAHULUAN}

Hasil wawancara dengan para siswa kelas VI Sekolah Dasar Negeri I Sanan, masih banyak siswa yang merasa enggan untuk mempelajari mata pelajaran tertentu termasuk mata pelajaran Matematika. Mata pelajaran Matematika di sekolah dasar adalah mata pelajaran yang terkait dalam kehidupan siswa baik sekarang maupun yang akan datang. Pelaksanaan pembelajaran menunjukkan bahwa siswa memiliki hasil belajar rendah. Indikator tersebut dapat dilihat dari berbagai hal, antara lain siswa kurang tertarik pada materi pelajaran Matematika dengan alasan materi sulit dan banyak sehingga aktivitas belajar kurang, mungkin juga siswa bosan dengan guru karena penerapan pembelajarannya kurang terkonsep dengan baik sehingga siswa kurang bersemangat mengikuti pelajaran yang mengakibatkan prestasi belajar siswa menurun. Ulangan harian Matematika pada materi akar pangkat tiga dari 13 siswa nilai rata-ratanya 57,69 dengan ketuntasan 38\% atau 5 siswa yang tuntas, 62\% atau 8 siswa yang belum tuntas, dan keaktifan proses pembelajaran kategori kurang. Aktivitas belajar siswa juga masih dalam kategori kurang aktif yaitu 11,31.

Berdasarkan analisis permasalahan di atas guru belum menerapkan model pembelajaran yang sesuai dengan materi sehingga banyak mendominasi proses pembelajaran, sehingga kurang memberi kesempatan pada siswa untuk aktif dan kreatif dalam menuangkan ide dan mempertajam gagasannya sehingga hasil belajar siswa $62 \%$ di bawah KKM.

Mata pelajaran Matematika tersebut tidak hanya berperan dalam ilmu pengetahuan saja, melainkan juga berperan pada kehidupan dan lingkungannya yang tercermin dalam kehidupan sehari-hari yang ditemui siswa secara berangsur-angsur, maka dari itu hal-hal tersebut di atas harus segera ditindaklanjuti sehingga kualitas pembelajaran perlu ditingkatkan dalam rangka meningkatkan hasil belajar siswa. Pembelajaran Matematika di kelas ini memerlukan suatu aktivitas pembelajaran yang dapat meningkatkan keterlibatan siswa. Kegiatan belajar mengajar tersebut diharapkan dapat meningkatkan hasil belajarnyayang salah satunya dengan penerapan model pembelajaran.

Menurut Joyce \& Well dalam Rusman (2012:133) model pembelajaran adalah suatu rencana atau pola yang dapat digunakan guru untuk membentuk kurikulum (rencana pembelajaran jangka panjang), merancang bahan pembelajaran dan membimbing pembelajaran di kelas atau yang lain. Model pembelajaran dapat dijadikan pola pilihan, artinya para guru boleh memilih model pembelajaran yang sesuai dengan karakteristik siswa dan tujuan yang akan dicapai. Hal ini, dimaksudkan agar tujuan pembelajaran dapat tercapai secara maksimal.

Terkait dengan upaya peningkatan kualitas pendidikan atau pembelajaran, banyak konsep yang ditawarkan diantaranya yaitu konsep pembelajaran dengan model SAVI yang didesain dengan kuis menyenangkan sesuai tingkat usia siswa kelas VI yaitu Eclipse Crossword. Pembelajaran materi akar pangkat tiga di SD didesain dengan model yang melibatkan semua indera siswa seperti yang terkonsep dalam pembelajaran model Somatic, Auditory, Visualization, Intellectualy (SAVI). Hal tersebut sangat dibutuhkan dalam pelaksanaan pembelajaran Matematika tentang akar pangkat tiga dan agar lebih menarik perhatian siswa. Model pembelajaran SAVI merupakan suatu pendekatan pembelajaran yang menekankan bahwa belajar haruslah memanfaatkan semua alat indera yang dimiliki oleh siswa". SAVI adalah Somatic-Learning by doing, Auditory-Learning by Hearing, Visual-Learning by seeing, Intellectual-Learning by thinking. (Miftahul Huda: 2013: 284). 
Pembelajaran dengan model SAVI akan didesain dengan permainan menyenangkan sesuai tingkat usia siswa kelas VI yaitu Crossword Puzzle atau tekateki silang. Menurut penelitian Davis et al (2009) menyatakan bahwa teka-teki silang efektif untuk belajar siswa. Pembuatan teka-teki silang ini rumit dan membutuhkan waktu lama, tetapi dengan bantuan kecanggihan teknologi masalah tersebut bisa teratasi. Penggunaan komputer/ laptop merupakan salah satu cara yang tepat dan bisa langsung dicetak. Dalam penelitian ini, TTS dibuat dengan menggunakan software eclipse crossword yang bisa diunduh bebas dari internet dan mudah digunakan oleh siswa kelas VI SD untuk meningkatkan daya tarik siswa terhadap pembelajaran. Hal tersebut sangat dibutuhkan dalam pelaksanaan pembelajaran Matematika materi akar pangkat tiga agar lebih menarik perhatian siswa. Crosword puzzle atau Teka Teki Silang (TTS) menurut Raines (2010:86) pertama kali diciptakan Arthur Wynne, seorang wartawan Inggris pada tahun 1913. TTS mendorong berpikir logis, pelafalan yang benar, dan bisa memotivasi siswa untuk mengetahui informasi faktual. TTS secara umum dipandang sebagai cara untuk menggunakan pengetahuan untuk belajar katakata baru atau fakta. TTS telah menunjukkan sebagai teknik mengajar yang efektif diberbagai disiplin ilmu seperti komunikasi, psikologi, dan keperawatan.

Sarnoko (2017: 29) menyatakan bahwa aktivitas siswa dalam pembelajaran merupakan rangkaian kegiatan yang meliputi keaktifan siswa dalam mengikuti pelajaran, baik bertanya, mencatat, mendengarkan, berfikir, membaca maupun melaksanakan segala kegiatan yang dapat menunjang prestasi belajar. Aktivitas dalam penelitian ini yaitu pengamatan oleh teman sejawat selama proses pembelajaran sesuai kriteria yang ditentukan dalam penerapan model SAVI berbasis Eclipse Crossword.

Sumaatmaja (2008) menyatakan bahwa hasil belajar dapat diklasifikasikan menjadi tiga domain yaitu ranah kognitif, ranah afektif dan ranah psikomotorik. Hasil belajar merupakan perubahan perilaku yang diperoleh pembelajar setelah mengalami aktivitas belajar. Dalam pembelajaran, perubahan perilaku yang harus dicapai oleh pembelajar setelah melaksanakan aktivitas belajar dirumuskan dalam tujuan pembelajaran. Tujuan pembelajaran merupakan deskripsi tentang perubahan perilaku yang diinginkan atau deskripsi produk yang menunjukkan bahwa belajar telah terjadi. Hasil belajar pada penelitian ini menggunakan tiga ranah yaitu kognitif, afektif, dan psikomotorik dengan prosentase yang berbeda yaitu kognitif $60 \%$, afektif $15 \%$, dan psikomotorik $25 \%$.

Berdasarkan latar belakang masalah di atas, maka masalah penelitian tindakan kelas ini adalah bagaimana proses pembelajaran melalui penerapan model SAVI untuk meningkatkan aktivitas dan hasil belajar materi akar pangkat tiga, seberapa banyak peningkatan aktivitas setelah penerapan model SAVI untuk meningkatkan aktivitas dan hasil belajar materi akar pangkat tiga, seberapa banyak peningkatan hasil belajar materi menentukan akar pangkat tiga setelah penerapan model SAVI berbasis Eclipse Crossword pada siswa kelas VI semester I Sekolah Dasar Negeri I Sanan Kecamatan Girimarto Kabupaten Wonogiri Tahun Pelajaran $2017 / 2018$.

Penelitian ini bertujuan untuk mendeskripsikan proses pembelajaran materi akar pangkat tiga setelah penerapan model SAVI berbasis Eclipse Crossword, mendeskripsikan peningkatan aktivitas setelah penerapan model SAVI berbasis Eclipse Crossword, mendeskripsikan peningkatan hasil belajar materi akar pangkat tiga setelah penerapan model SAVI berbasis Eclipse Crossword pada siswa kelas VI 
semester I Sekolah Dasar Negeri I Sanan Kecamatan Girimarto Kabupaten Wonogiri Tahun Pelajaran 2017/ 2018.

Manfaat bagi siswa dapat meningkatkan proses pembelajaran materi akar pangkat tiga setelah penerapan model SAVI berbasis SAVI berbasis Eclipse Crossword, dapat meningkatkan aktivitas setelah penerapan model SAVI berbasis Eclipse Crossword, dapat meningkatkan hasil belajar materi akar pangkat tiga setelah penerapan model SAVI berbasis Eclipse Crossword. Manfaat bagi guru memberikan gambaran kepada guru tentang pentingnya penerapan model SAVI berbasis Eclipse Crossword terkait dengan peningkatan aktivitas dan hasil belajar siswa, meningkatkan kinerja guru melalui perbaikan kualitas pembelajaran dengan menerapkan variasi model pembelajaran. Manfaat bagi teman sejawat sebagai bahan refleksi guru sebagai salah satu alternatif SAVI terkait dengan peningkatan aktivitas dan hasil belajar siswa, meningkatkan kinerja guru dengan menerapkan pembelajaran berbasis Eclipse Crossword untuk meningkatkan daya tarik siswa terhadap pembelajaran. Manfaat bagi sekolah meningkatkan aktivitas dan hasil belajar sekolah khususnya mata pelajaran Matematika, meningkatkan kualitas kompetensi lulusan dengan meningkatnya hasil Ujian Nasional. Manfaat bagi perpustakaan sekolah dapat menambah bacaan di perpustakaan sekolah.

\section{METODE PENELITIAN}

Metodologi berasal dari metode dan logi, metode berasal dari kata methodos yang berarti jalan atau cara yang harus dilalui untuk mencapai tujuan tertentu. Logi berasal dari bahasa Yunani yang artinya ilmu. Ulil Bukti Karo-Karo (1997: 7) menyatakan "metodologi berarti ilmu yang membicarakan tentang jalan atau cara yang harus dilalui untuk mencapai tujuan tertentu". Suatu penelitian memerlukan tempat penelitian yang akan dijadikan obyek untuk memperoleh data-data yang berguna untuk mendukung tercapainya tujuan penelitian. Penelitian ini dilaksanakan di SD Negeri 1 Sanan Kecamatan Girimarto Kabupaten Wonogiri. SD Negeri I Sanan memiliki 6 ruang kelas. Kelas yang digunakan dalam Penelitian Tindakan Kelas adalah siswa kelas VI.

Subjek dalam penelitian ini adalah siswa kelas VI SD Negeri I Sanan Kecamatan Girimarto Kabupaten Wonogiri tahun pelajaran 2017/ 2018 yang berjumlah 13 siswa terdiri dari 9 siswa laki-laki dan 4 siswa perempuan. Objek penelitian ini adalah mata pelajaran Matematika pada materi pokok akar pangkat tiga.

Ishak Aziz (2016:177) berpendapat bahwa sumber data adalah dari mana subjek yang dijadikan sumber data diperoleh. Zaenal Arifin (1998: 56) berpendapat bahwa sumber data adalah adalah tempat penulis bertumpu. Data atau informasi yang paling penting untuk dikumpulkan dan dikaji akan diperoleh sebagai data kualitatif. Informasi tersebut akan digali dari beragam sumber data dan jenis data yang akan dimanfaatkan dalam penelitian ini meliputi: 1) Informasi, yaitu dari nilai hasil ulangan, wawancara, dan catatan lapangan; 2) Lokasi dan Peristiwa meliputi a) Lokasi:

Ruang kelas VI SD Negeri I Sanan Kecamatan Girimarto Kabupaten Wonogiri; b) Peristiwa: Proses belajar mengajar dengan model SAVI berbasis Eclipse Crossword pada materi akar pangkat tiga; 3) Dokumentasi dan arsip berkaitan dengan proses tindakan berupa lembar observasi aktivitas siswa, wawancara, catatan lapangan dan hasil penilaian proses serta perilaku proses tindakan khususnya mata pelajaran Matematika pada materi akar pangkat tiga.

Teknik pengumpulan data adalah cara khusus yang dipergunakan untuk memperoleh data dalam penelitian. Data sangat diperlukan dalam penelitian guna 
membuktikan kebenaran suatu peristiwa atau pengetahuan. Oleh karena itu suatu penelitian sangat membutuhkan data yang objektif. Untuk mendapatkan data yang objektif perlu diperhatikan mengenai teknik pengumpulan data yang digunakan sebagai alat pengumpul data atau pengambil data. Dalam penelitian tindakan kelas, baik data kualitatif maupun kuantitatif dimanfaatkan untuk menggambarkan perubahan yang terjadi yaitu: 1) perubahan pada kinerja guru; 2) perubahan kinerja siswa; dan 3) perubahan suasana kelas dari keadaan awal yang kurang aktif berubah pada kondisi akhir dimana aktivitas siswa meningkat seiring dengan meningkatnya prestasi belajar siswa tersebut. Pengumpulan data menggunakan 2 metode, yaitu: 1) Metode test untuk mengetahui peningkatan hasil belajar melalui penerapan model SAVI berbasis Eclipse Crossword. Instrumen tes yang digunakan dalam penelitian ini berupa tes hasil belajar kognitif, afektif, psikomotorik. Bentuk tes hasil belajar yang diberikan adalah tes tertulis dalam bentuk uraian. Suharsimi Arikunto (2010:193) menyatakan bahwa tes adalah serentetan pertanyaan atau latihan serta alat lain yang digunakan untuk mengukur keterampilan, pengetahuan intelegensi, kemampuan atau bakat yang dimiliki individu atau kelompok; 2) Metode observasi untuk mengetahui perkembangan aktivitas siswa dan guru yang dilakukan oleh teman sejawat sebagai penilainya, berupa lembar observasi, wawancara, catatan lapangan, dan dokumentasi.

Menurut Suharsimi Arikunto dkk (2008: 12) di dalam penelitian diperlukan adanya validitas data, maksudnya adalah semua data yang dikumpulkan hendaknya mencerminkan apa yang sebenarnya diukur atau diteliti. Penelitian ini untuk menguji kesahihan data digunakan triangulasi data dan triangulasi metode. Adapun yang dimaksud kedua hal tersebut adalah 1) Triangulasi data adalah data atau informasi yang diperoleh selalu dikomparasikan dan diuji dengan data dan informasi lain, baik dari segi koheren sumber yang sama atau sumber yang berbeda. Untuk menggali data yang sejenis biasa diperoleh dari nara sumber (manusia), dari kondisi lokasi, dari aktivitas yang menggambarkan perilaku atau dari sumber yang berupa catatan atau arsip yang memuat catatan yang berkaitan dengan data yang dimaksud. Pada penelitian ini data perbandingan nilai mata pelajaran Matematika materi akar pangkat tiga dengan mata pelajaran lain pada kurun waktu satu tahun. Data nilai ulangan harian tersebut secara langsung, selain itu juga beberapa informasi dari orang tua wali siswa kelas VI tentang kesulitan yang dialami putra-putrinya khususnya pada mata pelajaran Matematika akar pangkat tiga. Dengan cara ini data sejenis teruji kemantapan dan kebenarannya dari sumber data yang berbeda-beda; 2) Triangulasi metode yaitu mengumpulkan data sejenis dengan menggunakan metode pengumpulan data yang berbeda. Selain itu menggunakan metode pengumpulan data yang berupa observasi kemudian dilakukan wawancara yang mendalam dari informan yang sama dan hasilnya diuji dengan pengumpulan data sejenis dengan menggunakan teknik dokumentasi pada pelaku kegiatan. Data yang diperoleh dari yang diperoleh lewat beberapa teknik pengumpulan data yang berbeda tersebut hasilnya dibandingkan dan dapat ditarik kesimpulan data yang lebih kuat validitasnya.

Analisis data adalah proses mengorganisasikan dan mengurutkan data ke dalam pola, kategori, dan satuan uraian dasar sehingga ditemukan tema dan dapat dirumuskan hipotesis kerja seperti yang disarankan oleh data. Jadi analisis data dalam penelitian ini dilaksanakan setelah data diperoleh dengan cara mengurutkan data yang telah dikumpulkan ke dalam kelompok tertentu. Model analisis yang digunakan adalah model silang terjalin atau interaktif. Berdasarkan pendapat Miles dan Huberman (2014: 15-20) pengumpulan data dan pengolahan data lebih jelasnya dalam model ini ada tiga komponen analisis yaitu reduksi data, pengajian data dan penarikan kesimpulan atau verifikasi dilakukan dalam bentuk interaktif dengan proses siklus. Dalam bentuk analisis ini bergerak dalam empat komponen yaitu dari proses pengumpulan data, 
reduksi data, penyajian data dan penarikan kesimpulan atau verifikasi, yang dapat diuraikan sebagai berikut: 1) Pengumpulan data yaitu merupakan kegiatan untuk mengumpulkan data dari informasi secara langsung maupun dari dokumen dan arsip yang berhubungan dengan permasalahan yang diteliti; 2) Reduksi data yaitu merupakan kegiatan untuk memilih-milih data yang telah diperoleh di lapangan, dalam hal ini ditekankan pada hal-hal pokok dan penting yang disusun secara sistematis. Data yang direduksi dapat memberikan gambaran yang lebih tajam tentang hasil pengamatan, hal ini mempermudah peneliti untuk mencari kembali data yang diperlukan; 3) Sajian data dimaksudkan untuk mempermudah dalam melihat gambaran keseluruhan atau bagian-bagian tertentu dari penelitian. Salah satu caranya yaitu membuat suatu tabel, yang isinya dibuat menurut kebutuhan, sesuai dengan aspek yang ingin dimunculkan atau dinampakkan; 4) Penarikan kesimpulan atau verifikasi yaitu engambil kesimpulan merupakan langkah analisis data yang dilaksanakan segera setelah data diperoleh. Kesimpulan yang diambil kemungkinan masih terasa kabur dan diragukan. Oleh karena itu perlu dicari data yang mendukung kesempurnaan kesimpulan dengan cara melalui variabel. Jadi yang dimaksud verifikasi adalah mencari data baru untuk menguatkan kesimpulan yang telah diambil.

Pawito (2008: 104) menyatakan bahwa reduksi data bukan asal membuang data yang tidak diperlukan, melainkan merupakan upaya yang dilakukan peneliti selama analisis data dilakukan dan merupakan langkah yang terpisahkan dari analisi data. Reduksi data, penyajian data dan penarikan kesimpulan/ verifikasi sebagai suatu yang jalin menjalin pada saat sebelum dan sesudah pengumpulan data dalam bentuk yang sejajar untuk membangun wawasan umum yang disebut "analisis". Teknik analisis mengikuti pola bersumber pada pola analisis interaktif. Model analisis itu antar unsur dalam penelitian (reduksi data, sajian data dan kesimpulan) saling berinteraksi. Tidak ada batas yang memisahkan antar unsur-unsur pada proses penelitian pada tingkat verifikasi kalau dirasakan perlu untuk memantapkan hasil penelitian atau dibutuhkan data baru sehingga dapat memantapkan kesimpulan. Pada proses verifikasi sering melangkah kembali pada tahap reduksi data, sehingga triangulasi data selalu berhubungan dalam proses penelitian.

Indra Bastian (2005: 267) berpendapat bahwa indikator kinerja adalah ukuran kuantitatif dan kualitatif yang menggambarkan tingkat pencapaian suatu sasaran atau tujuan yang telah ditetapkan, dengan memperhatikan indikator masukan (inputs), keluaran (outputs), hasil (outcomes), manfaat (benefits), dan dampak (impacts). Indikator kinerja merupakan rumusan kinerja yang akan dijadikan acuan atau tolak ukur dalam menentukan keberhasilan atau keefektifan penelitian. Indikator kerja adalah alat untuk mengukur keberhasilan suatu tindakan. Dalam indikator kerja memuat indikator kerja itu sendiri, kriteria keberhasilan, target dari penelitian dan alat pengumpulan data. Indikator kinerja yang ingin dicapai dalam penelitian ini adalah meningkatnya hasil belajar SD Negeri I Sanan Kecamatan Girimarto Kabupaten Wonogiri. Indikator penelitian ini bersumber dari kurikulum dan silabus KTSP mata pelajaran Matematika pada materi tersebut yaitu akar pangkat tiga serta dengan Kriteria Ketuntasan Minimal yaitu 75. 


\section{HASIL DAN PEMBAHASAN}

\section{Hasil Penelitian Prasiklus}

Hasil observasi aktivitas siswa prasiklus dapat kita lihat pada tabel berikut ini:

Tabel 1. Data Observasi Aktivitas Siswa Prasiklus

\begin{tabular}{|l|l|c|c|}
\hline No & \multicolumn{1}{|c|}{ Kriteria } & Frekuensi & Prosentase \\
\hline 1 & Sangat Aktif & 0 & $0 \%$ \\
\hline 2 & Aktif & 0 & $0 \%$ \\
\hline 3 & Cukup Aktif & 4 & $31 \%$ \\
\hline 4 & Kurang Aktif & 9 & $69 \%$ \\
\hline \multicolumn{2}{|l|}{ Rata - rata } & 11,31 dengan kriteria "Kurang Aktif" \\
\hline
\end{tabular}

Berdasarkan tabel 1 observasi pada prasiklus dapat dibuat grafik pada gambar 1 berikut:

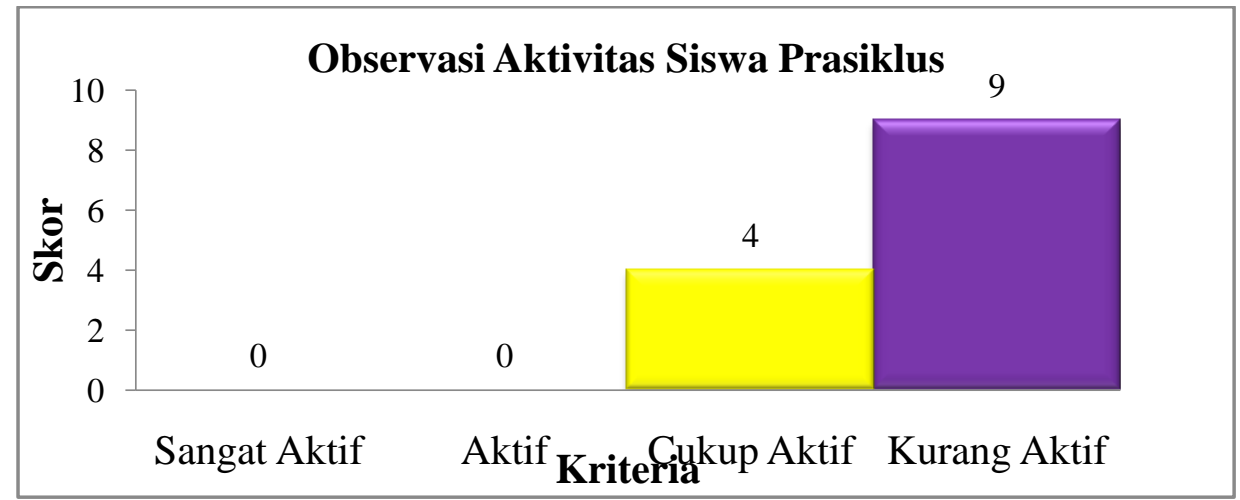

Gambar 1. Grafik Observasi Aktivitas Siswa Prasiklus

Dari data pada tabel 1 menunjukkan bahwa 9 siswa atau $69 \%$ tergolong dalam kriteria aktivitas kurang aktif, 4 siswa atau 31\% tergolong dalam kriteria aktivitas cukup aktif, sedangkan tidak ada siswa untuk kriteria aktivitas aktif dan sangat aktif. Berdasarkan hasil observasi siswa diatas diperoleh nilai rata-rata 11,31 dengan kriteria kurang aktif.

Berdasarkan nilai dan aktivitas pada prasiklus tersebut, maka dapat disimpulkan bahwa kemampuan pada materi akar pangkat tiga kelas VI SD Negeri I Sanan masih kurang.

Daftar nilai pada prasiklus yang diperoleh siswa dengan KKM 75 untuk nilai 40 sebanyak 6 siswa, nilai 50 sebanyak 1 siswa, nilai 60 sebanyak 1 siswa, nilai 80 sebanyak 5 siswa dengan jumlah total 750 ; rata-ratanya 57,69 ; nilai tertinggi 80 ; nilai terendah 40; nilai yang tuntas yaitu 5 siswa; nilai yang belum tuntas 8 siswa; ketuntasan yaitu $38 \%$; belum tuntas yaitu $62 \%$. Dari daftar nilai siswa prasiklus dapat dibuat frekuensi nilai siswa prasiklus pada tabel 2 sebagai berikut: 
SHEs: Conference Series 1 (1) (2018) 758-772

Tabel 2. Data Nilai Siswa Prasiklus

\begin{tabular}{|l|c|c|c|}
\hline No & Kelas Interval & Frekuensi & $\begin{array}{c}\text { Prosentase } \\
(\%)\end{array}$ \\
\hline 1 & $<56$ & 7 & 54 \\
\hline 2 & $56-62$ & 1 & 8 \\
\hline 3 & $63-68$ & 0 & 0 \\
\hline 4 & $69-74$ & 0 & 0 \\
\hline 5 & $75-81$ & 5 & 38 \\
\hline 6 & $82-88$ & 0 & 0 \\
\hline 7 & $89-94$ & 0 & 0 \\
\hline 8 & $95-100$ & 0 & 0 \\
\hline Jumlah & 13 & 100 \\
\hline
\end{tabular}

Berdasarkan tabel 2 frekuensi nilai tes awal maka dapat digambarkan grafik pada gambar 2:

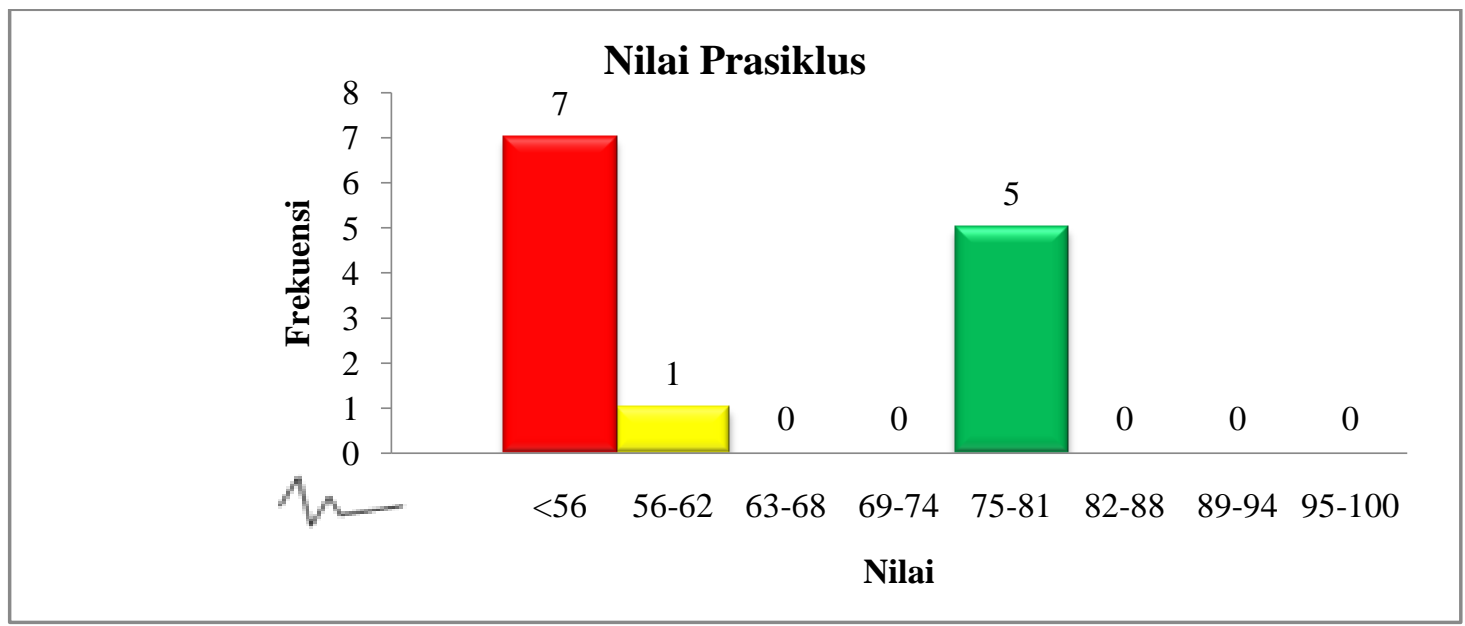

Gambar 2. Grafik Nilai Prasiklus

Berdasarkan gambar grafik tersebut siswa kelas VI SD Negeri I Sanan yang berjumlah 13 siswa, frekuensi nilai $<56$ sejumlah 7 anak, yang bernilai 56-62 sejumlah 1 siswa, tidak ada siswa yang bernilai 63-68, tidak ada siswa yang bernilai 69-74, nilai 75-81 sejumlah 5 siswa. Dari data nilai siswa, hanya 5 siswa atau 38\% memperoleh nilai sesuai dengan Kriteria Ketuntasan Minimal (KKM). Sebanyak 8 siswa atau $62 \%$ memperoleh nilai di bawah batas nilai ketuntasan yaitu 75 , dari pihak sekolah ketuntasan siswa diharapkan mencapai $80 \%$.

Berdasarkan data dari keaktifan proses pembelajaran, aktivitas siswa, dan hasil belajar pada prasiklus tersebut, maka dapat disimpulkan bahwa hasil belajar pada materi akar pangkat tiga pada kelas VI SD Negeri I Sanan belum sesuai dengan harapan.

\section{Hasil Penelitian Siklus I} dibuat tabel 3.

Dari hasil penelitian pada siklus 1 , dapat dilihat hasil observasi siswa dapat 
Tabel 3. Observasi Aktivitas Siswa Siklus I

\begin{tabular}{|l|l|c|c|}
\hline No & Kriteria & Frekuensi & Prosentase \\
\hline 1 & Sangat Aktif & 0 & $0 \%$ \\
\hline 2 & Aktif & 4 & $31 \%$ \\
\hline 3 & Cukup Aktif & 4 & $31 \%$ \\
\hline 4 & Kurang Aktif & 5 & $38 \%$ \\
\hline \multicolumn{2}{|l|}{ Rata - rata } & 15,54 dengan kriteria "cukup aktif" \\
\hline
\end{tabular}

Berdasarkan tabel 3 nilai observasi pada siklus I dapat dibuat grafik pada gambar 3.

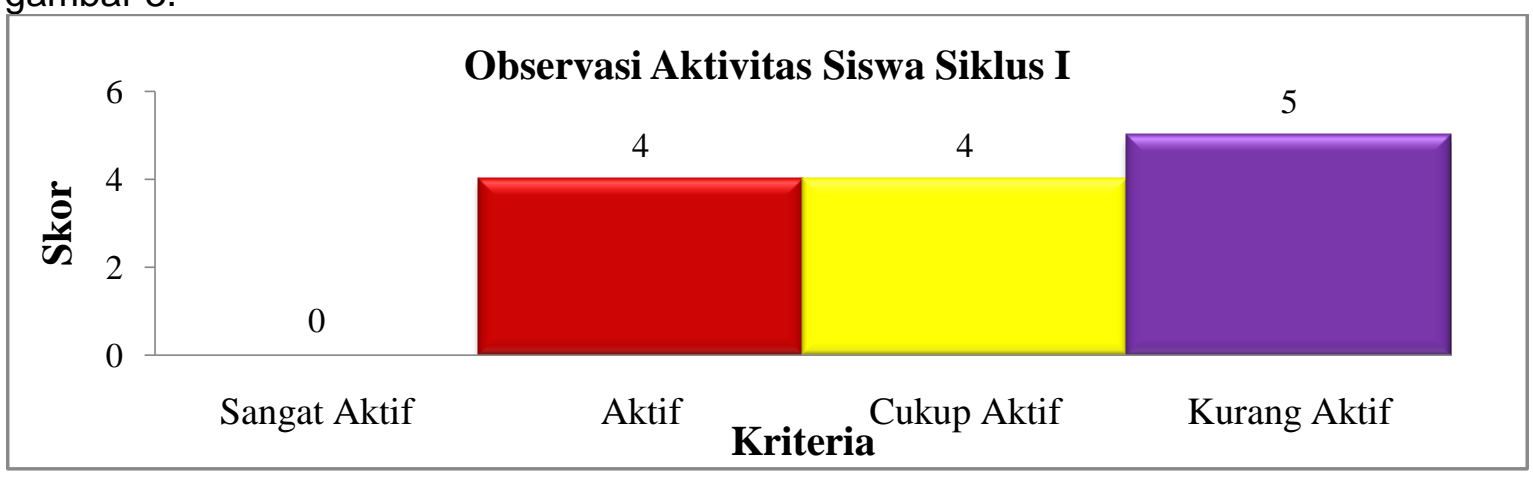

Gambar 3. Grafik Observasi Aktivitas Siswa Siklus I

Dari data pada gambar 3 menunjukkan bahwa tidak ada siswa yang mendapat kriteria sangat aktif, ada 4 siswa atau 31\% tergolong dalam kriteria aktif, ada 4 siswa atau $31 \%$ tergolong dalam kriteria aktivitas cukup aktif sedangkan masih ada 5 siswa atau $38 \%$ mendapatkan kriteria kurang aktif. Berdasarkan hasil observasi siswa diatas diperoleh nilai rata-rata 15,54 dengan kriteria cukup aktif.

Daftar nilai pada siklus I yang diperoleh siswa dengan KKM 75 untuk nilai 56 sebanyak 1 siswa, nilai 62 sebanyak 2 siswa, nilai 78 sebanyak 2 siswa, nilai 80 sebanyak 1 siswa, nilai 81 sebanyak 5 siswa, nilai 92 sebanyak 1 siswa, nilai 98 sebanyak 1 siswa dengan jumlah total 1.009; rata-ratanya 77,61 ; nilai tertinggi 98 ; nilai terendah 56; nilai yang tuntas yaitu 10 siswa; nilai yang belum tuntas 3 siswa; ketuntasan yaitu $77 \%$; belum tuntas yaitu $23 \%$. Dari daftar nilai siswa siklus I dapat dibuat frekuensi nilai siswa siklus I pada tabel 4 sebagai berikut:

Tabel 4. Data Nilai Siswa Siklus I

\begin{tabular}{|l|l|l|l|}
\hline No & Kelas Interval & Frekuensi & Prosentase (\%) \\
\hline 1 & $<63$ & 3 & 23 \\
\hline 2 & $63-68$ & 0 & 0 \\
\hline 3 & $69-74$ & 0 & 0 \\
\hline 4 & $75-81$ & 8 & 61 \\
\hline 5 & $82-87$ & 0 & 0 \\
\hline 6 & $88-93$ & 1 & 8 \\
\hline 7 & $94-100$ & 1 & 8 \\
\hline \multicolumn{2}{|l}{ Jumlah } & 13 & 100 \\
\hline
\end{tabular}


Berdasarkan tabel 4 frekuensi nilai Matematika pada siklus I dapat dilihat grafik pada gambar 4:

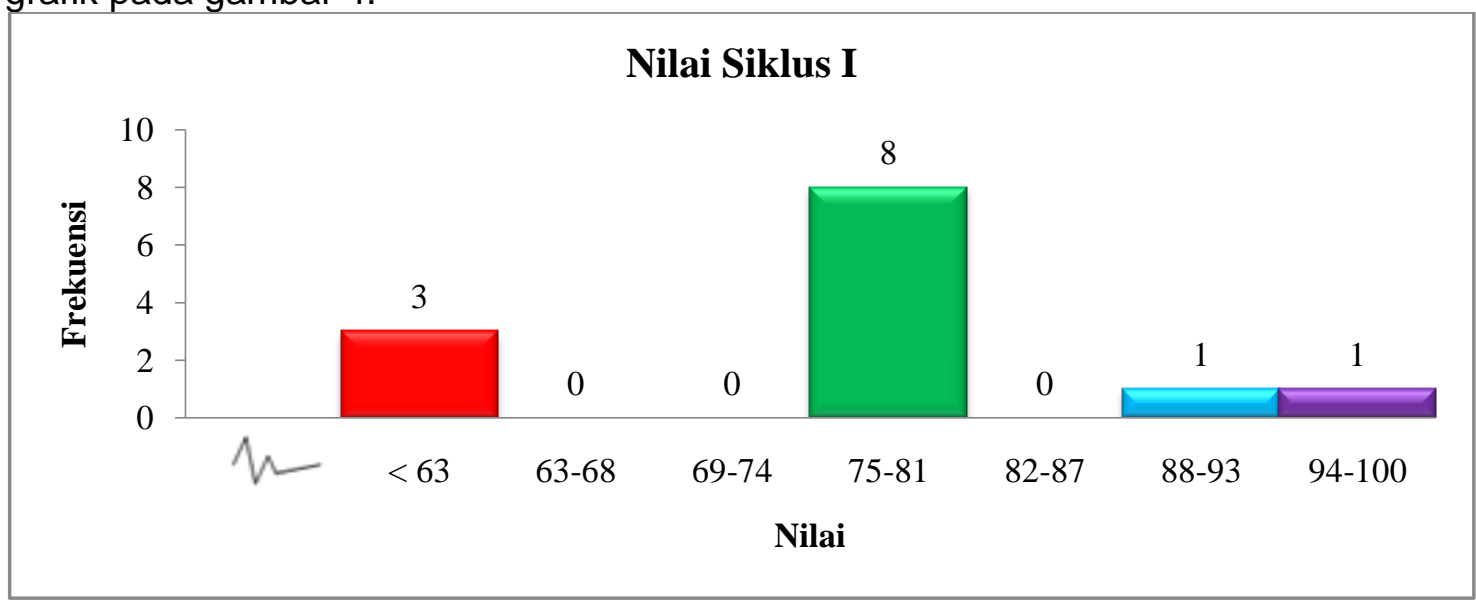

Gambar 4. Grafik Nilai Siklus I

Dari data gambar 4 , siswa yang memperoleh nilai pada rentang $<63$ sebanyak 3 siswa atau $23 \%$, tidak ada siswa yang mendapat nilai pada rentang $63-68$, tidak ada siswa yang bernilai pada rentang 69-74, terdapat 8 siswa yang bernilai 75-81 atau $61 \%$, tidak ada siswa yang bernilai pada rentang $82-87$, pada rentang $88-93$ sebanyak 1 siswa atau $8 \%$ dan pada rentang 94-100 sebanyak 1 siswa atau $8 \%$ yang mencapainya.

Berdasarkan data nilai di atas dapat dilihat bahwa pada siklus I, siswa kelas VI SD Negeri 1 Sanan sebanyak 13 siswa dengan keterangan 10 siswa atau $77 \%$ memperoleh nilai di atas batas nilai ketuntasan minimal. Sebanyak 3 siswa atau $23 \%$ memperoleh nilai di bawah batas nilai ketuntasan. Dari data tersebut diperoleh nilai terendah 56 dan nilai tertinggi adalah 98, sehingga didapat rata-rata nilai kelas yaitu 77,61 .

Dari data nilai di atas maka dapat disimpulkan bahwa nilai siklus I meningkat. Pada siklus I jumlah siswa belajar tuntas sebesar $77 \%$, yang semula pada pra tindakan $38 \%$.

\section{Hasil Penelitian Siklus II}

Tabel 5. Observasi Aktivitas Siswa Siklus II

\begin{tabular}{|l|l|l|l|}
\hline No & Kriteria & Frekuensi & Prosentase \\
\hline 1 & Sangat Aktif & 4 & $31 \%$ \\
\hline 2 & Aktif & 7 & $54 \%$ \\
\hline 3 & Cukup Aktif & 2 & $15 \%$ \\
\hline 4 & Kurang Aktif & 0 & $0 \%$ \\
\hline \multicolumn{2}{|l|}{} & \multicolumn{2}{|c|}{} \\
\hline \multicolumn{2}{|l|}{ Rata - rata } & 24,85 dengan kriteria "aktif" \\
\hline
\end{tabular}
gambar 5

Berdasarkan tabel 5 nilai observasi pada siklus II dapat dibuat grafik pada 


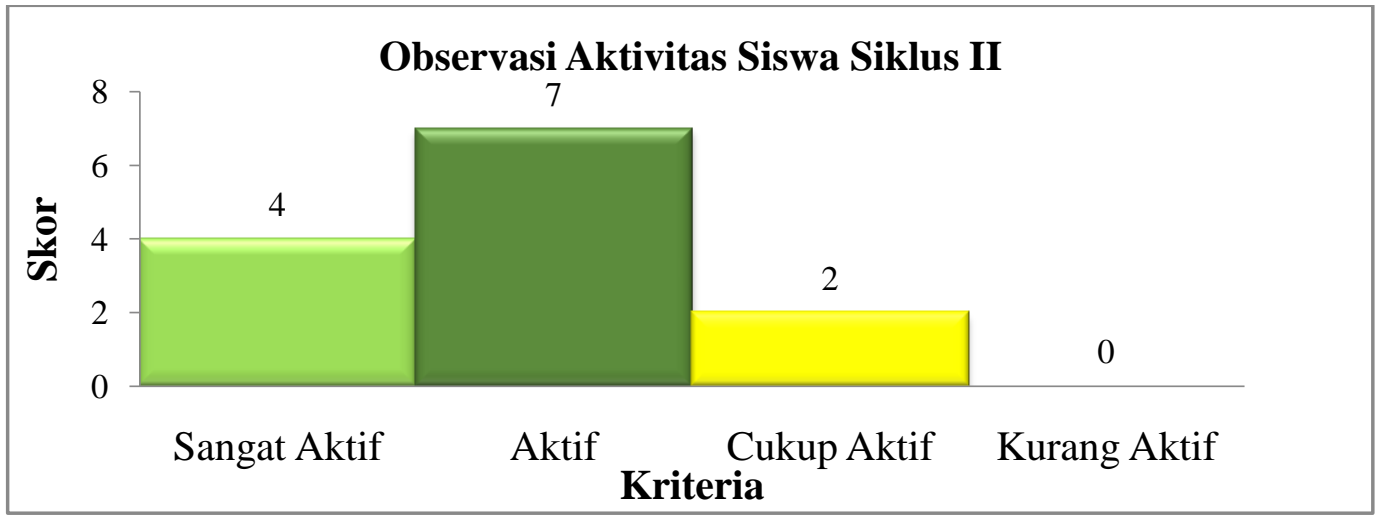

Gambar 5. Grafik Observasi Aktivitas Siswa Siklus II

Dari data pada tabel 5 menunjukkan bahwa 4 siswa atau $31 \%$ tergolong dalam kriteria Aktivitas sangat aktif, 7 siswa atau 54\% tergolong dalam kriteria aktivitas yang aktif, ada 2 siswa atau 15\% siswa yang tergolong aktivitas kriteria cukup aktif, dan tidak ada siswa pada kriteria kurang aktif. Berdasarkan hasil observasi siswa diatas diperoleh nilai rata-rata 24,85 dengan kriteria aktif.

Dari data observasi aktivitas siswa di atas maka dapat disimpulkan bahwa pencapaian observasi aktivitas siswa siklus II meningkat. Pada siklus I hasil observasi aktivitas siswa diperoleh nilai rata-rata 15,54 dengan kriteria cukup aktif dan pada siklus II, hasil observasi aktivitas siswa diatas diperoleh nilai rata-rata 24,85 dengan kriteria aktif.

Daftar nilai pada siklus II yang diperoleh siswa dengan KKM 75 untuk nilai 62 sebanyak 1 siswa, nilai 68 sebanyak 1 siswa, nilai 81 sebanyak 1 siswa, nilai 83 sebanyak 1 siswa, nilai 88 sebanyak 1 siswa, nilai 89 sebanyak 2 siswa, nilai 90 sebanyak 2, nilai 98 sebanyak 1 siswa, nilai 99 sebanyak 3 siswa dengan jumlah total 1.135; rata-ratanya 87,33; nilai tertinggi 99; nilai terendah 62; nilai yang tuntas yaitu 11 siswa; nilai yang belum tuntas 2 siswa; ketuntasan yaitu $85 \%$; belum tuntas yaitu $15 \%$. Dari data nilai siswa siklus II dapat dibuat frekuensi nilai siswa siklus II pada tabel 6 sebagai berikut:

Tabel 6. Data Nilai Siswa Siklus II

\begin{tabular}{|l|l|l|l|}
\hline No & Kelas Interval & Frekuensi & Prosentase (\%) \\
\hline 1 & $<69$ & 2 & 15 \\
\hline 2 & $69-74$ & 0 & 0 \\
\hline 3 & $75-81$ & 1 & 8 \\
\hline 4 & $82-87$ & 1 & 8 \\
\hline 5 & $88-93$ & 5 & 38 \\
\hline 6 & $94-100$ & 4 & 31 \\
\hline \multicolumn{2}{|l}{ Jumlah } & 13 & 100 \\
\hline
\end{tabular}

Berdasarkan tabel 6 frekuensi nilai Matematika pada siklus II dapat dilihat grafik pada gambar 6 : 
SHEs: Conference Series 1 (1) (2018) 758-772

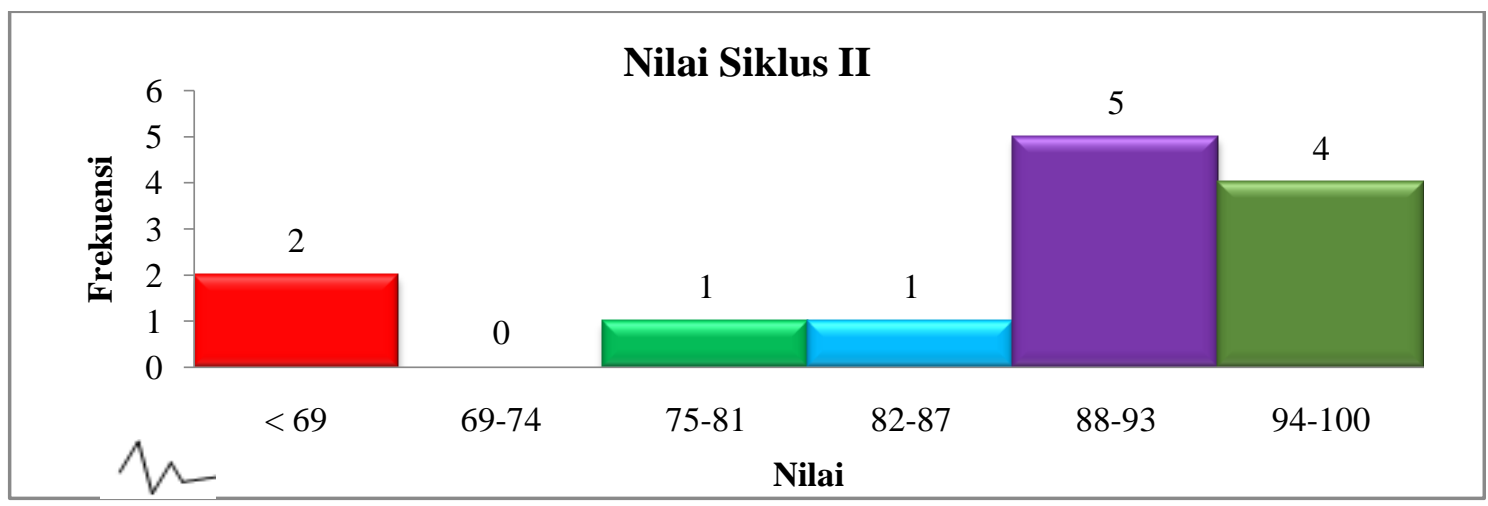

Gambar 6. Grafik Nilai Siklus II

Dari data gambar 6 , siswa yang memperoleh nilai pada rentang < 69 sebanyak 2 siswa atau 15\%, tidak ada siswa yang mendapat nilai pada rentang 69-74, rentang 75-81 sebanyak 1 siswa atau $8 \%$, rentang 82-87 sebanyak 1 siswa atau $8 \%$, rentang 88-93 sebanyak 5 atau 38\% siswa dan 94-100 sebanyak 4 siswa atau $31 \%$ yang mencapainya.

Berdasarkan data nilai di atas dapat dilihat pada bahwa pada siklus II, siswa kelas VI SD Negeri 1 Sanan sebanyak 13 siswa dengan keterangan 11 siswa atau 85 $\%$ memperoleh nilai di atas batas nilai ketuntasan minimal. Sebanyak 2 siswa atau $15 \%$ memperoleh nilai di bawah batas nilai ketuntasan. Dari data tersebut diperoleh nilai terendah 62 dan nilai tertinggi adalah 99, sehingga rata-rata nilai kelas yaitu 87 , 33.

Dari data nilai diatas maka dapat disimpulkan bahwa nilai siklus II meningkat. Pada siklus II, jumlah siswa belajar tuntas sebesar $85 \%$, yang semula pada prasiklus $38 \%$ dan pada siklus I sebesar $77 \%$.

\section{Pembahasan Hasil Penelitian}

Berdasarkan hasil pelaksanaan pada siklus I dan siklus II dapat dinyatakan bahwa penerapan model SAVI dapat meningkatkan aktivitas dan hasil belajar Matematika materi akar pangkat tiga pada siswa kelas VI Sekolah Dasar Negeri I Sanan Kecamatan Girimarto Kabupaten Wonogiri tahun pelajaran 2017/ 2018. Perkembangan nilai terus meningkat dari tiap siklusnya

Tabel 7. Perkembangan Aktivitas Siswa dari Prasiklus, Siklus I, dan Siklus II.

\begin{tabular}{llll}
\hline Aktivitas Siswa & Prasiklus & Siklus I & Siklus II \\
Sangat Aktif & $0 \%$ & $0 \%$ & $31 \%$ \\
Aktif & $0 \%$ & $31 \%$ & $54 \%$ \\
Cukup Aktif & $31 \%$ & $31 \%$ & $15 \%$ \\
Kurang Aktif & $69 \%$ & $38 \%$ & $0 \%$ \\
Rata-rata Aktivitas & 11,31 & 15,54 & 24,85 \\
Jumlah Kenaikan Rata-rata Aktivitas & & 4,23 & 9,31 \\
\hline
\end{tabular}

Dari tabel 7 dapat digambarkan grafik pada gambar 7: 


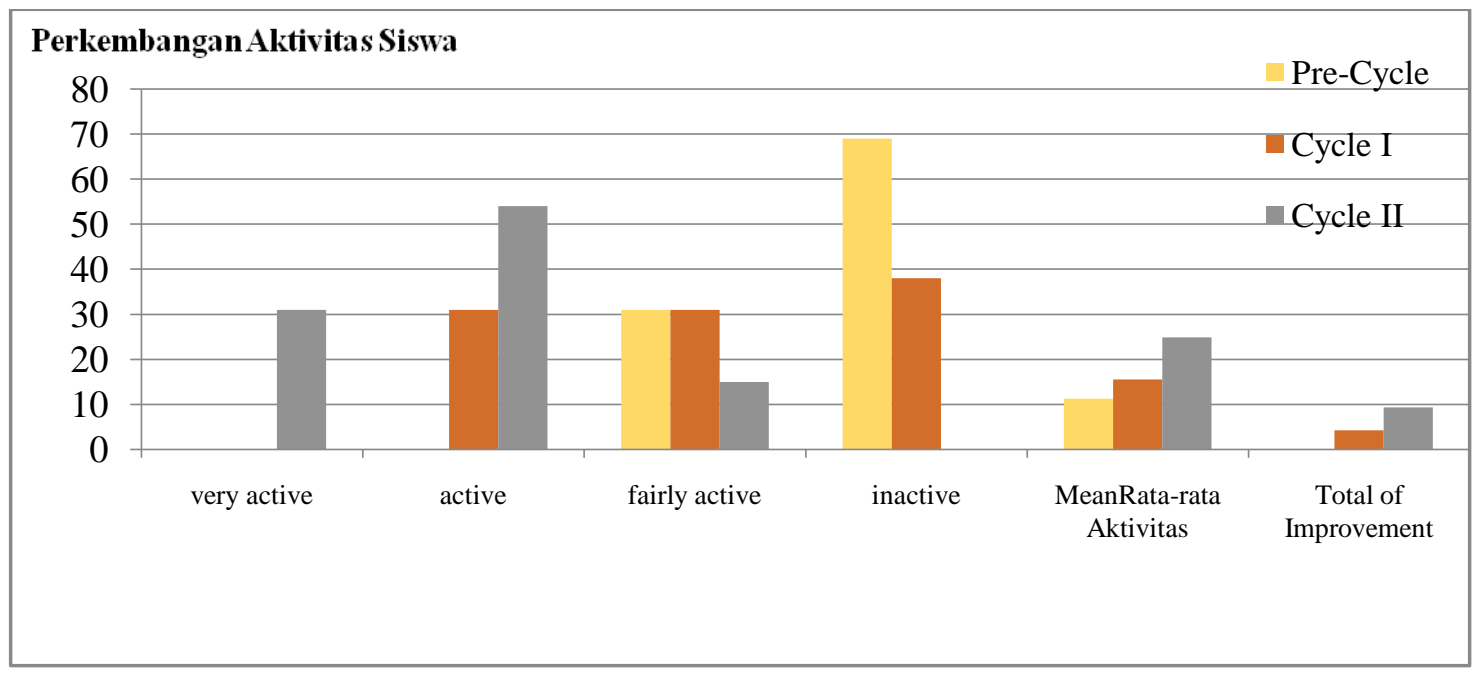

Gambar 7. Perkembangan Aktivitas Siswa Prasiklus, Siklus I, Siklus II

Aktivitas siswa dari prasiklus untuk kriteria sangat aktif belum ada, begitu juga pada kriteria aktif, kriteria cukup aktif terdapat 4 siswa atau $31 \%$, kriteria kurang aktif terdapat 9 siswa atau 69\%. Rata-rata aktivitas pada prasiklus yaitu 11,31 dengan kriteria kurang aktif. Perkembangan rata-rata observasi aktivitas siswa dari siklus I untuk kriteria sangat aktif belum ada, pada kriteria aktif 4 siswa atau 31\%, kriteria cukup aktif terdapat 4 siswa atau 31\%, kriteria kurang aktif terdapat 5 siswa atau 38\%. Rata-rata aktivitas pada siklus I yaitu 15,54 dengan kriteria cukup aktif. Perkembangan rata-rata observasi aktivitas siswa dari siklus II untuk kriteria sangat aktif ada 4 siswa atau $31 \%$, pada kriteria aktif 7 siswa atau 54\%, kriteria cukup aktif terdapat 2 siswa atau $15 \%$, tidak ada siswa pada kriteria kurang aktif. Rata-rata aktivitas pada siklus II yaitu 24,85 dengan kriteria aktif.

Peningkatan nilai rata-rata aktivitas dari prasiklus ke siklus I yaitu 4,24 dan dari siklus I ke siklus II yaitu 9,31. Rata-rata aktivitas pada prasiklus 11,31 dengan kriteria kurang aktif, siklus I rata-rata 15,54 dengan kriteria cukup aktif, dan siklus II 24,85 dengan kriteria aktif. Hasil tersebut telah memenuhi indikator kinerja yaitu siswa mendapatkan kriteria aktif, maka dikatakan telah memenuhi indikator kinerja.

Perkembangan nilai siswa dari prasiklus hingga siklus II.

Tabel 8. Perkembangan Nilai Siswa dari Prasiklus, Siklus I, dan Siklus II

\begin{tabular}{llll}
\hline Keterangan & Prasiklus & Siklus I & Siklus II \\
Nilai Tertinggi & 80 & 98 & 99 \\
Nilai Terendah & 50 & 62 & 68 \\
Rata-rata & 56,92 & 78,08 & 87,79 \\
Siswa Tuntas & $38 \%$ & $77 \%$ & $85 \%$ \\
Jumlah Kenaikan Nilai Rata-rata & & 16,23 & 9,71 \\
Jumlah Kenaikan Prosentase Ketuntasan Nilai & & $39 \%$ & $8 \%$ \\
\hline
\end{tabular}

Dari tabel 8 maka dapat digambarkan grafik perkembangan nilai siswa dari prasiklus, siklus I, dan siklus II yaitu dapat dilihat pada gambar 8: 


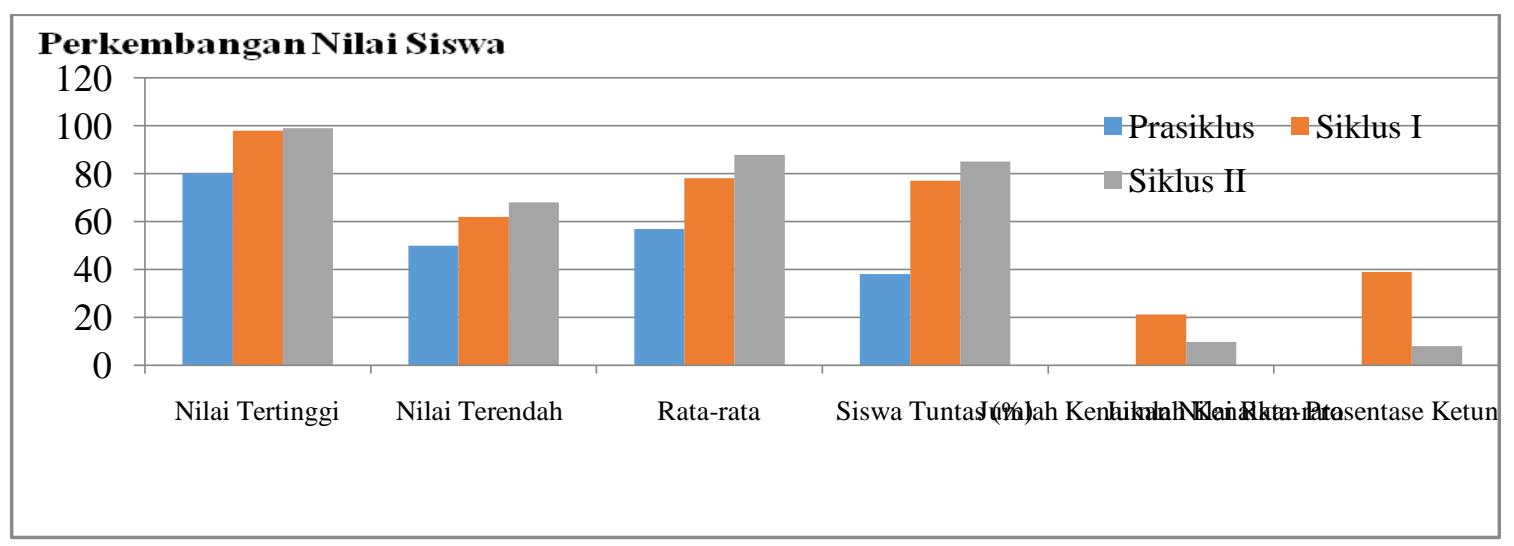

Gambar 8. Perkembangan Nilai Siswa Prasiklus, Siklus I, Siklus II

Peningkatan nilai siswa tersebut tercapai secara bertahap. Dimulai dari nilai prasiklus dengan nilai tertinggi 80 dan nilai terendah 40, rata-rata nilai prasiklus yaitu 57,69 hanya mencapai ketuntasan $38 \%$ dari KKM. Hal ini dapat dilihat bahwa siswa yang mendapat nilai yang memenuhi KKM hanya 5 siswa sedangkan yang tidak memenuhi KKM berjumlah 8 siswa. Maka dapat dikatakan nilai siswa pada materi Menentukan posisi titik dalam Akar pangkat tiga siswa sangat kurang. Nilai siklus I dengan nilai tertinggi 98 dan nilai terendah 56, rata-rata nilai siklus I yaitu 77,61 mencapai ketuntasan $77 \%$ dari KKM. Hal ini dapat dilihat bahwa siswa yang mendapat nilai yang memenuhi KKM 10 siswa sedangkan yang tidak memenuhi KKM berjumlah 3 siswa. Maka dapat dikatakan nilai siswa pada materi Akar pangkat tiga ada peningkatan. Nilai siklus II dengan nilai tertinggi 99 dan nilai terendah 62, rata-rata nilai siklus II yaitu 87,33 mencapai ketuntasan 85\% dari KKM. Hal ini dapat dilihat bahwa siswa yang mendapat nilai yang memenuhi KKM 11 siswa sedangkan yang tidak memenuhi KKM berjumlah 2 siswa. Maka dapat dikatakan nilai siswa pada materi Akar pangkat tiga ada peningkatan.

\section{SIMPULAN}

Berdasarkan hasil penelitian dan pembahasan, dapat disimpulkan bahwa penerapan model SAVI berbasis SAVI berbasis Eclipse Crossword dapat meningkatkan aktivitas dan hasil belajar siswa kelas VI SD Negeri I Sanan Kecamatan Girimarto Kabupaten Wonogiri tahun pelajaran 2017/ 2018.

Berdasarkan simpulan hasil penelitian tersebut, maka dapat disampaikan saran-saran sebagai berikut: 1) sebaiknya guru menerapkan model SAVI berbasis Eclipse Crossword dalam menyampaikan materi akar pangkat tiga dengan mendesain proses pembelajaran secara kreatif dan bervariatif, sehingga pembelajaran lebih kondusif dan representatif, sehingga siswa tidak merasakan kebosanan dalam proses pembelajaran yang pada akhirnya motivasi dan prestasi belajar; 2) kepala sekolah hendaknya lebih meningkatkan pengawasan kepada guru-guru kelasnya dalam menentukan strategi pembelajaran terutama dalam memilih model pembelajaran yang tepat sesuai dengan materi bahan ajar agar proses pembelajaran efisien dan efektif dalam upaya peningkatan mutu pendidikan; 3) Hasil penelitian ini terbuka untuk dikaji lebih jauh dan dikembangkan sehingga dapat digeneralisasikan pada materi pokok yang lain; 4) siswa harus lebih meningkatkan motivasi, aktivitas belajar, keaktifan dan keberanian mengemukakan pendapat dalam proses pembelajaran untuk menambah wawasan dan prestasi belajar meningkat. 


\section{DAFTAR PUSTAKA}

Davis, T.M., Shepherd, B., \& Zwiefelhofer, T. (2009). Reviewing for Exam: Do Crossword Puzzle Help in the Succes of Student Learning. The Journal of effective Teaching. University of Wisconsin, River Falls. (Online),(www.insightjournal.net) Diakses tanggal 7 Agustus 2017.

Indra Bastian. 2005. Akuntansi Sektor Publik. Jakarta: Erlangga.

Ishak Aziz. 2016. Dasar-dasar Penelitian Olahraga. Jakarta: Kencana.

Joyce, B. \& Weil, M. 2011. Models of Teaching Model Model Pengajaran, Edisi Kedelapan, Terjemahan Ahmad Fawaid dan Atailla Mirza. Yogyakarta: PustakaPelajar.

Miftahul Huda.2013. Model-model Pengajaran dan Pembelajaran. Yogyakarta : Pustaka Pelajar.

Milles, M.B. \& Huberman, A.M. 2014. Analisis Data Kualitatif. (Terjemahan Tjetjep Rohendi Rohidi). Jakarta: Universitas Indonesia Press.

Pawito. 2008. Penelitian Komunikasi Kualitatif. Yogyakarta: LKIS Yogyakarta.

Raines, D.A. 2010. An Innovation to facilitate Student Engagement and Learning: Crossword Puzzles in The Classroom. Teaching and Learning in Nurse. (Online), 5 : 85-90, (www.jtln.org) diakses 7 Agustus 2017.

Sarnoko. 2014. Penerapan Pendekatan SAVI untuk Meningkatkan Aktivitas dan Hasil Belajar. Yogyakarta: Lingkarantarnusa

Suharsimi Arikunto, Suharjo dan Supardi. 2008. Penelitian Tindakan Kelas. Jakarta : PT. bumi Aksara.

Suharsimi Arikunto. 2010. Prosedur Penelitian Suatu Pendekatan Praktik. Jakarta: Rineka Cipta.

Sumaatmadja. 2008. Konsep Dasar IPS. Jakarta: Universitas Terbuka.

Ulil Bukti Karo-Karo S.1997. Metodologi Pengajaran. Salatiga : Saudara.

Zaenal Arifin. 1998. Dasar-dasar Penulisan Karya IImiah. Jakarta: Grasindo. 